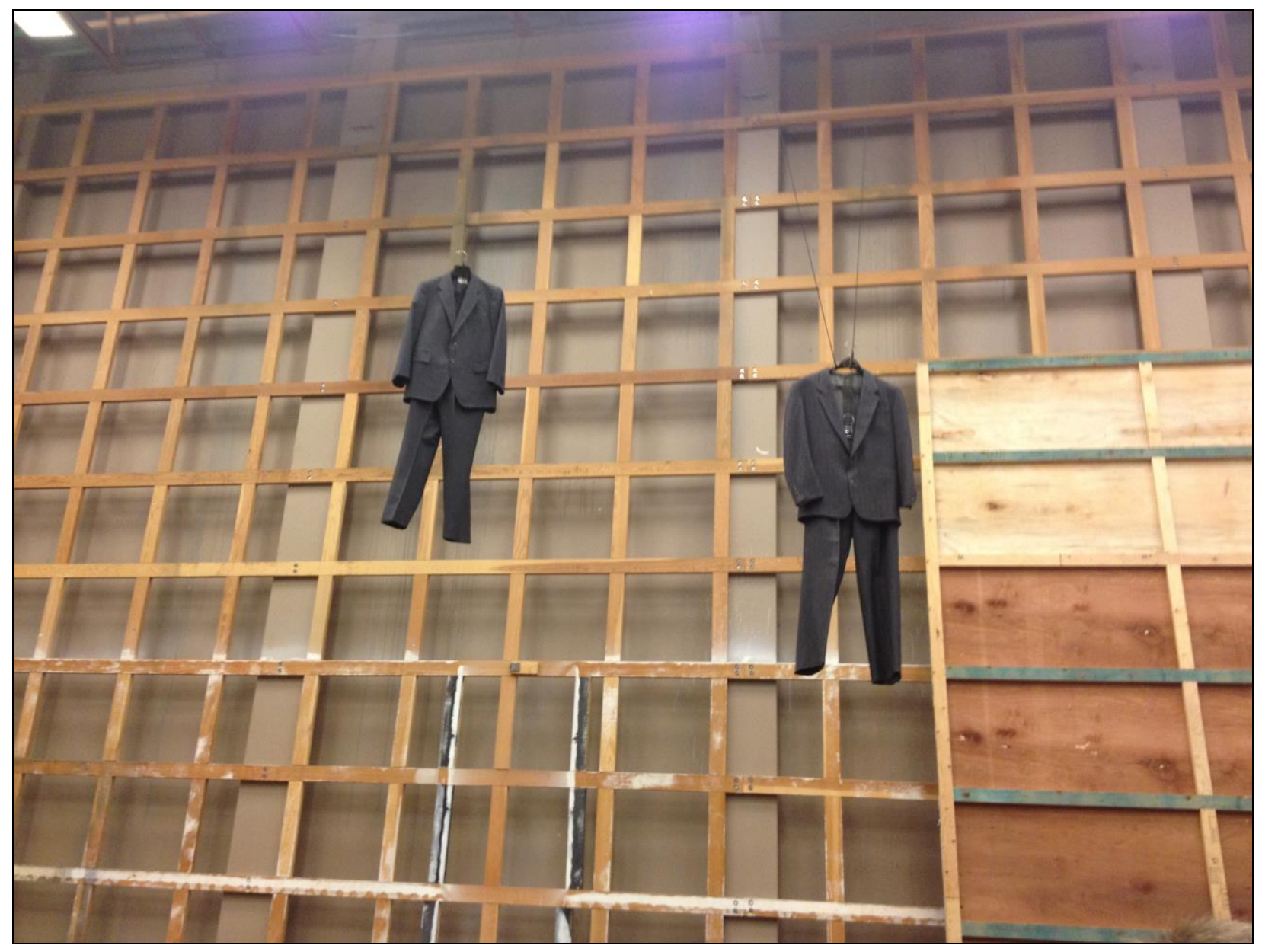

Photo credit: Elena Siemens

\title{
The Absent One
}

Stefano Muneroni University of Alberta, Canada

The Absent One, translated and adapted from Xavier Villaurrutia's El ausente by Stefano Muneroni, and staged during the 2013 StageLAB Festival hosted by the Department of Drama. "Nocturnos de los Ángeles," a poem also by Villaurrutia, concluded this theatrical adaptation by bringing to life the image of suspended suits as representation of gay angels. Staging this play provided a public forum to remember a great Mexican writer who is hardly known in North America. The Absent One "remembered" Villaurrutia's Spanish text by giving voice to its loud silences about homoeroticism and by opening up new critical avenues to look at its author. Confident that memory does not retrieve the past, but rather interprets and reconfigures it in light of the present, the translator aspired to remember/adapt Villaurrutia for a contemporary audience. 


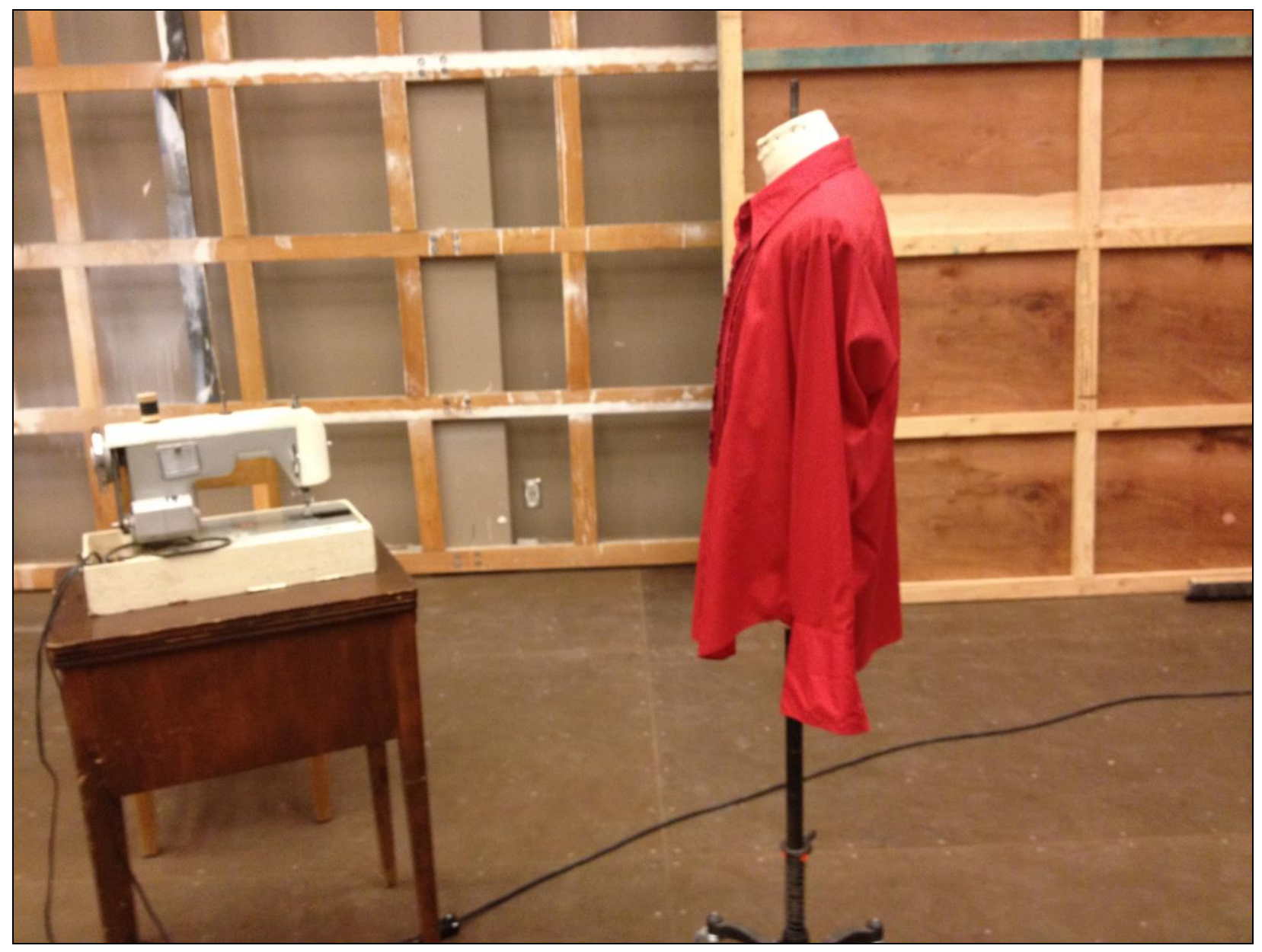

Photo credit: Elena Siemens

\section{“Nocturno de los Ángeles” by Xavier Villaurrutia}

Se diría que las calles fluyen

dulcemente en la noche.

Las luces no son tan vivas que logren desvelar el secreto,

el secreto que los hombres que van y vienen conocen,

porque todos están en el secreto

y nada se ganaría con partirlo en mil pedazos

si, por el contrario, es tan dulce guardarlo

y compartirlo sólo con la persona elegida.

Si cada uno dijera en un momento dado, en sólo una palabra, lo que piensa,

las cinco letras del DESEO formarían una enorme cicatriz luminosa, una constelación más antigua, más viva aún que las otras.

Y esa constelación sería como un ardiente sexo en el profundo cuerpo de la noche, 
TranscUlturAl, vol. 8.1 (2016), 166-171.

http://ejournals.library.ualberta.ca/index.php/TC

o, mejor, como los Gemelos que por vez primera en la vida

se miraran de frente, a los ojos, y se abrazaran ya para siempre.

De pronto el río de la calle se puebla de sedientos seres,

caminan, se detienen, prosiguen.

Cambian miradas, atreven sonrisas,

forman imprevistas parejas...

Hay recodos y bancos de sombra, orillas de indefinibles formas profundas

y súbitos huecos de luz que ciega

y puertas que ceden a la presión más leve.

El río de la calle queda desierto un instante.

Luego parece remontar de sí mismo

deseoso de volver a empezar.

Queda un momento paralizado, mudo, anhelante

como el corazón entre dos espasmos.

Pero una nueva pulsación, un nuevo latido

arroja al río de la calle nuevos sedientos seres.

Se cruzan, se entrecruzan y suben.

Vuelan a ras de tierra.

Nadan de pie, tan milagrosamente

que nadie se atrevería a decir que no caminan.

¡Son los ángeles!

Han bajado a la tierra

por invisibles escalas.

Vienen del mar, que es el espejo del cielo,

en barcos de humo y sombra,

a fundirse y confundirse con los mortales,

a rendir sus frentes en los muslos de las mujeres, a dejar que otras manos palpen sus cuerpos febrilmente, y que otros cuerpos busquen los suyos hasta encontrarlos como se encuentran al cerrarse los labios de una misma boca, a fatigar su boca tanto tiempo inactiva, a poner en libertad sus lenguas de fuego, a decir las canciones, los juramentos, las malas palabras en que los hombres concentran el antiguo misterio de la carne, la sangre y el deseo. 
TranscUlturAl, vol. 8.1 (2016), 166-171.

http://ejournals.library.ualberta.ca/index.php/TC

Tienen nombres supuestos, divinamente sencillos.

Se llaman Dick o John, o Marvin o Louis.

En nada sino en la belleza se distinguen de los mortales.

Caminan, se detienen, prosiguen.

Cambian miradas, atreven sonrisas.

Forman imprevistas parejas.

Sonríen maliciosamente al subir en los ascensores de los hoteles

donde aún se practica el vuelo lento y vertical.

En sus cuerpos desnudos hay huellas celestiales;

signos, estrellas y letras azules.

Se dejan caer en las camas, se hunden en las almohadas

que los hacen pensar todavía un momento en las nubes.

Pero cierran los ojos para entregarse mejor a los goces de su encarnación misteriosa, y, cuando duermen, sueñan no con los ángeles sino con los mortales.

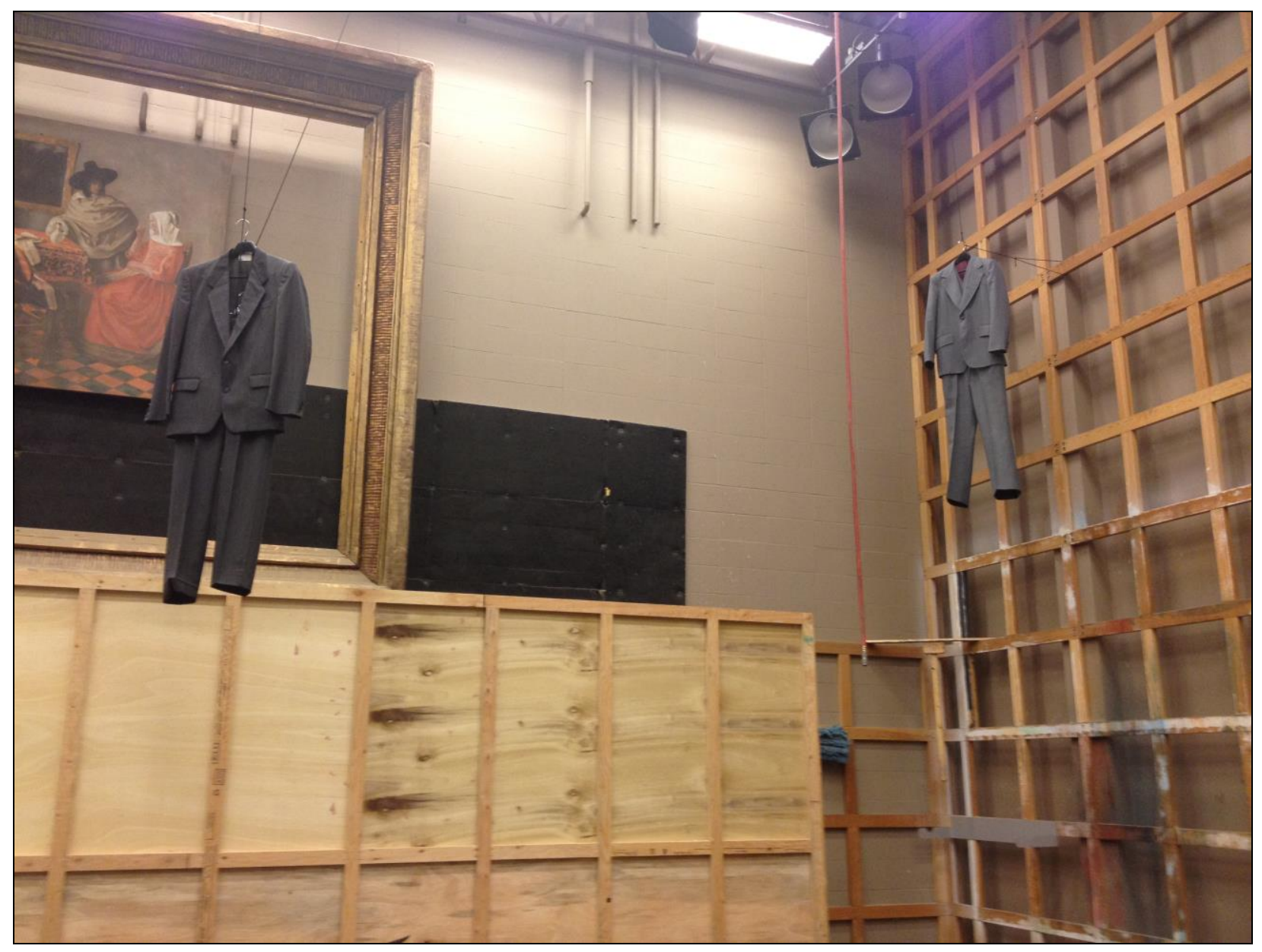

Photo credit: Elena Siemens 
TranscUlturAl, vol. 8.1 (2016), 166-171.

http://ejournals.library.ualberta.ca/index.php/TC

\section{Translation by Stefano Muneroni}

The streets flow smoothly through the night.

The lights are opaque enough to hide the secret.

The secret known only to the men who ceaselessly come and go. They all know the secret and guard it jealously.

Nothing would come of sharing it.

The secret is sweet and enjoyed best with the chosen ones.

If they all uttered in unison the one word in their mind,

the six letters of the word "desire" would appear in the sky like a resplendent scar. They would form a constellation more lasting than all the others;

A constellation that burns like sex in the hollowed body of the night,

Like the Gemini who see each other's faces and eyes for the first time, and spend the rest of their lives embracing.

Thirsty men move like a river in the street.

They walk, they stop, they stare at each other, dare to smile, and form unpredictable couples...

There are corners and benches in the shadows.

Blinding lights suddenly cut indefinable shapes on deep riverbanks, and doors open at the softest touch.

For a moment, the river of men slows down,

Stops for an instant, paralyzed, deaf, longing like a heart caught between two spasms;

Then its tide returns, eager to begin again.

A new thrusting pulse, a throbbing heartbeat

Bring to the street new parched bodies.

They cross once and again, take off and float close to the ground.

They swim standing up,

So miraculously that nobody would ever doubt they are really walking.

They are Angels who descended to earth with invisible ladders;

They come from the sea, that is the mirror of the sky, on boats made of shadows and smoke,

To fuse and disguise themselves among men,

To surrender their foreheads to the thighs of women,

To let other hands feverishly touch their bodies,

To let other bodies search for theirs until they are finally found, Like lips find themselves when they close and know they are 'one.' 
TranscUlturAl, vol. 8.1 (2016), 166-171.

http://ejournals.library.ualberta.ca/index.php/TC

They come to tire their gaping mouths,

To exhaust their tongues of fire,

To spell out the songs, the vows, the sensual words

In which men have coalesced the mystery of flesh, blood, and desire. Their names are wondrous and simple: Miguel, Paco, Francisco, or Luis. They are distinguishable from mortals only by their beauty.

They walk, they stop, they stare at each other, dare to smile, and form unpredictable couples... They smile maliciously in hotel elevators where they can still practice slow vertical flight.

There are heavenly marks on their naked bodies: signs, stars, and blue letters.

They allow themselves to fall into beds and sink into pillows so they can feel again what it means to be still in the clouds.

But they shut their eyes to yield more utterly to the pleasures of their incarnation. And when they sleep, they dream not of angels but of men. 